Boston University School of Law

Scholarly Commons at Boston University School of Law

Faculty Scholarship

2005

Family Privacy and Death: Antigone, War, and Medical Research

George J. Annas

Follow this and additional works at: https://scholarship.law.bu.edu/faculty_scholarship

Part of the Health Law and Policy Commons 


\title{
Family Privacy and Death - Antigone, War, and Medical Research
}

\author{
George J. Annas, J.D., M.P.H.
}

Death ends the doctor-patient relationship, and legally the patient's right of privacy dies with the patient. Other privacy interests survive, the most central of which are those of the patient's family to bury the body and to prevent the disclosure of some personal information, such as medical information, about the deceased relative. Just what privacy interests encompass and when they can be overridden by other interests - such as freedom of speech or the claims of public policy or medical research - are evolving. ${ }^{1}$ Family privacy concerning a family member who has died is at the forefront of a continuing political dispute in the United States and is the subject of two recent major court rulings, one in the United States and another in Iceland. Only one of these examples directly involves physicians, but all three help to illuminate the concept of family privacy in the context of death, an issue that must be taken seriously in health care.

THE DOVER TEST

The political dispute concerns the policy of the Department of Defense not to permit the press to photograph or film the flag-draped coffins of soldiers killed in war as they arrive from abroad at Dover Air Force Base. The "Dover test" is shorthand for how many casualties the American public can tolerate before a war becomes politically unsustainable. The policy of banning the filming of the coffins was first put into place by then Secretary of Defense Dick Cheney after President George H.W. Bush was televised laughing during an unrelated press conference on one half of a split screen while coffins of American soldiers returning from Panama at Dover were shown on the other half of the screen. The ban was retained during Operation Desert Storm, generally not followed during President Bill Clinton's administration, and reinstated at the outset of the war in Iraq. ${ }^{2}$

The original policy was challenged in court, and the Court of Appeals for the District of Columbia upheld it. ${ }^{3}$ The court concluded that the First Amendment did not give the press unlimited access to government installations and that family interests supported the policy: the interest in reducing the hardship of the families who would be under pressure to travel to Dover if public arrival ceremonies were held there (ceremonies are instead held at the soldiers' home bases), and "the interest in protecting the privacy of families and friends of the dead, who may not want media coverage of the unloading of caskets at Dover." ${ }^{3}$ The court noted that the family's privacy interest depends on the ability of outsiders to identify the particular soldier in the closed casket, but nonetheless concluded, "We do not think the government [is] hypersensitive in thinking that the bereaved may be upset at public display of the caskets of their loved ones." ${ }^{3}$

But if there is really no way to identify the soldier in the casket, publication of a photograph does not implicate family privacy. In April 2004, for example, the Air Force responded to a request based on the Freedom of Information Act by releasing hundreds of photographs of flag-covered coffins at Dover. In the cover letter Colonel Laurel A. Warish wrote, "We removed all personally identifying information of the remains as release could rekindle grief, anguish, pain, embarrassment, or disrupt the peace of mind of surviving family members, invading their privacy." ${ }^{4}$ The photographs were posted on a Web site (www.thememoryhole.org) and published by all the major media. Subsequently, the administration of President George W. Bush indicated that the official photos were provided in error and that the no-press policy would continue. ${ }^{5}$ On the one hand, of course, the administration may not want the official photos published for political reasons. On the other hand, it is plausible to argue that even though specific individual soldiers cannot be identified as occupying specific coffins, the family members of recently killed soldiers may nonetheless feel that 
their privacy is being violated by the publication of such photos.

Although there is apparently no consensus among military families on the issue, the National Military Family Association has taken the position that "the privacy of families of the departed service members" is important and that "sensitivity to the grief of surviving families should be paramount [so that] how much the press is able to intrude at this very difficult time should be at the discretion of the individual family." ${ }^{6}$ This position would permit families, rather than the government or the press, to determine whether photos of identifiable caskets can be taken, and even whether the press may be present when the caskets arrive at Dover.

In June 2004, the Senate voted 54 to 39 to retain the press-ban policy. Senator John McCain (R-Ariz.) made the proper policy point, noting that "these caskets that arrive at Dover are not named; we just see them. . . . I think we ought to know the casualties of war."7

THE FOSTER PHOTOGRAPHS

Another case based on the Freedom of Information Act explores family privacy in the context of death more directly. As President Clinton wrote in his autobiography, in July 1993 his lifelong friend and White House counsel, Vincent W. Foster, Jr., committed suicide using "an old revolver that was a family heirloom." ${ }^{8}$ Foster left a note, which read, in part, "I was not meant for the job in the spotlight of public life in Washington. Here ruining people is considered sport." ${ }^{8}$ He was found dead in Fort Marcy Park, and the park police conducted the initial investigation and took photographs of the scene, including 10 color photographs of Foster's body.

Despite five separate investigations that determined that Foster's death was a suicide, conspiracy theorists continued to be skeptical. One of them, Allan Favish, sought the public release of the photographs of the scene of the death under the Freedom of Information Act. His request as counsel for the organization Accuracy in Media to the National Park Service was denied, and the denial was affirmed in court. Favish then sought the photographs as an individual citizen from Kenneth Starr, head of the Office of Independent Counsel, arguing that the government's investigations of Foster's death were "grossly incomplete and untrustworthy." Foster's widow and sister joined the case, arguing against disclosure. Starr denied the request, but a lower court ultimately granted Favish access to five of the photographs. ${ }^{9}$

The lower court ruled that exception 7(c) to the Freedom of Information Act - that records can be withheld from the public if they "could reasonably be expected to constitute an unwarranted invasion of personal privacy" - did not apply to the Foster photographs. ${ }^{9}$ The case was appealed to the Supreme Court, which unanimously reversed the ruling, thus rejecting disclosure of the photographs. The opinion was written by Justice Anthony M. Kennedy. ${ }^{10}$ The Court made it clear that the members of the Foster family were not attempting to enforce Vincent Foster's own privacy interests in making sure that the pictures did not harm his reputation posthumously or other personal interests. Instead, Foster's family had the right to "invoke their own right and interest to personal privacy" and to "seek to be shielded by the exemption [7(c)] to secure their own refuge from a sensation-seeking culture for their own peace of mind and tranquility, not for the sake of the deceased." ${ }^{10}$ In a sworn declaration, for example, Foster's sister noted that she was "horrified and devastated" by a photograph that had already been leaked to the press: "I have nightmares and heart-pounding insomnia as I visualize how he must have spent his last few minutes and seconds of his life." She added, "Releasing any photographs would constitute a painful unwarranted invasion of my privacy."10

As the Court construed it, the question was whether Congress had intended that the phrase "personal privacy" be read "to permit family members to assert their own privacy rights against public intrusions long deemed impermissible under the common law and in our cultural traditions." ${ }^{10}$ The Court found in U.S. "case law and traditions the right of family members to direct and control disposition of the body of the deceased and to limit attempts to exploit pictures of the deceased family member's remains for public purposes." The Court continued by observing that families have had the principal say with regard to the burial and disposition of dead bodies "in almost all civilizations from time immemorial," citing, among other examples, Sophocles' portrayal of Antigone and her heroic insistence on performing the burial rites for her brother, even though he had been branded a traitor by the king according to martial law and her actions were punishable by death.

The Court noted further that a family's interest in burying their dead relatives had been extended 
in decisions by other courts to criminal records, autopsy records, and photographs of the deceased. The Court believed that Congress understood this context when it amended exemption 7(c) to the Freedom of Information Act to extend its terms. The Court argued further that additional interests are protected by family privacy, including the ability of the government to deny requests based on the Freedom of Information Act for autopsy records and photographs of their victims by rapists, murderers, and other violent criminals, noting that "we find it inconceivable that Congress could have intended a definition of 'personal privacy' so narrow that it would allow convicted felons to obtain these materials without limitations at the expense of surviving family members' personal privacy." 10

The Court thus had little trouble concluding that family members had a privacy interest in the photographs of the scene of Foster's death. But the Court also had to find that the invasion of their privacy was "unwarranted" in order to uphold the government's denial of access to the photographs. The Court determined that where there is a privacy interest that is protected by the exception and the public interest asserted for disclosure is "to show that responsible officials acted negligently or otherwise improperly in the performance of their duties, the requester must . . . produce evidence that would warrant a belief by a reasonable person that the alleged Government impropriety might have occurred." ${ }^{10}$ Since Favish produced no such evidence (e.g., testimony from someone involved in the investigation), the Court reversed the lower court's decision and ruled that the Foster photographs be kept from the public on the basis of family privacy. ${ }^{10}$

THE ICELAND CASE

Research on genetic variation appears to be a constantly growing field, one that was pioneered in Iceland by the private biotechnology firm deCODE genetics in a private-public project to develop and link three databanks (one consisting of computerized medical records, a second of samples of DNA, and a third of genealogic data) in an effort to locate disease-related genes. The project has been controversial since 1998, when Iceland's legislature approved the creation of a computerized Health Sector Database for deCODE's use for research. ${ }^{11,12}$ One of the important concerns has been the failure of the legislature to require informed consent; instead, patients were given the opportunity to "opt out" of having their computerized medical records included in the database. In late 2003, the Iceland Supreme Court dealt with the issue of informed consent from the perspective of family privacy, asking whether families have a privacy interest in the medical records of deceased relatives sufficient to permit them to "opt out" of the national database on the behalf of the deceased relative. ${ }^{13}$

Guomundur Igolfsson died in 1991, and in 2000 his daughter, then 15 years of age, requested, through her guardian, that the medical director of health prohibit the transfer of information from her father's medical records to the national Health Sector Database. In January of that year, the minister of health had formally authorized the deCODE genetics project to create and operate the database. The medical director denied the daughter's request, stating, among other things, that it was not the intention of the enabling legislation that people should be able to refuse on behalf of their deceased parents. The daughter, joined by her two brothers, appealed the ruling, and the case was ultimately heard by Iceland's Supreme Court. ${ }^{13}$

The supreme court, after noting that the Health Sector Database had not yet come into use and that "some doubt this will happen," nonetheless decided to deal directly with the question of family medical privacy. ${ }^{13}$ The court noted, first, that, as in the United States, under Icelandic law "the personal rights of individuals lapse on their death insofar as legislation does not provide otherwise" and that the law creating the Health Sector Database did not provide for any right of descendants to exercise the privacy rights of the deceased. ${ }^{13}$ Thus, the only privacy rights the daughter could assert were her own (which, in fact, was what she was asserting). Specifically, she argued that she had a personal interest in preventing the transfer of her father's records to the database, because "it is possible to infer, from the data, information relating to her father's hereditary characteristics which could also apply to herself."13

Medical records, as the court observed, contain significant amounts of private information, including about patients' "medical treatment, lifestyles, social circumstances, employment and family. . . . Information of this kind can relate to some of the most intimately private affairs of the person concerned, irrespective of whether the information is seen as derogatory for the person or not." ${ }^{13}$ The court had no difficulty concluding that Article 71 of the Constitution of Iceland (according to which "Everyone shall enjoy the privacy of his or 
her life, home, and family") guarantees protection of the privacy of medical information, requiring the legislature to ensure, among other things, "that legislation does not result in any actual risk of information of this kind involving the private affairs of identified persons falling into the hands of parties who do not have any legitimate right of access to such information. . . ."13

The mere possibility that someone might obtain "information from medical records without the explicit consent of the person whom the information concerns" does not necessarily violate the constitution, the court ruled, but the constitution does require the legislature "to ensure to the furthest extent that the information cannot be traced to specific individuals." 13 The court was unequivocal in declaring that "the achievement of this stated objective is far from being adequately ensured by the provisions of statutory law."13 This means that the law creating the Health Sector Database is unconstitutional. This ruling killed whatever was left of deCODE's original project to create a countrywide computerized database of medical records. ${ }^{14}$

With regard to the petition before it, the Supreme Court of Iceland ruled that the daughter "may herself have an interest in preventing the transfer of information from her father's medical records into the Health Sector Database because of the risk that inferences could be made from such information which could concern her private affairs." ${ }^{13}$ Since the enabling legislation does not adequately protect the constitutional privacy rights of individuals by making health data untraceable, the right of the daughter to prohibit the use of her father's medical data is recognized as part of her own right of privacy.

FAMILY PRIVACY AND THE DEAD

We have become accustomed to thinking about privacy as a personal right. We have also become accustomed, especially in the United States, to seeing the right of privacy applied in health care settings, including in decision making about one's medical treatment, in the privacy of information within the doctor-patient relationship generally, and in the use of medical information and DNA samples for research. These three examples support an individualistic view of privacy. They also indicate, however, that in matters of public policy, statutory interpretation, and even constitutional adjudication, the concept of privacy is being broadened to protect the family unit from unwanted and unwarranted intrusion by both government and private actors. The court rulings provide family members with control not only over the bodies of deceased relatives but also over at least some of the private information about these relatives.

This development represents, as the Supreme Court noted, a repudiation of Creon's legal decree forbidding Antigone from burying her brother in its protection of family privacy in death, even in the case of war and in cases involving high public officials. How powerful this trend is remains to be seen, but these examples suggest that both the public and the courts support it. One implication of the trend is that families will probably continue to be protected against proposals such as presumed consent, which would permit the routine harvesting of organs from their dead relatives without the family's consent.

As potentially powerful as the concept of family privacy is, however, it is never absolute. We may decide that it is reasonable and respectful to accord family members the right to decide for themselves whether the press may photograph the flag-draped coffins of family members killed in the wars in Afghanistan and Iraq when they arrive at Dover Air Force Base. But it would be unreasonable to decide that on the basis of family privacy the press may never photograph such flag-draped coffins. There is no family privacy right to prohibit the filming of family members in public places, even family members killed on the battlefield or in earthquakes or floods. It also seems reasonable to reject the requests of the simply curious, the criminal, or amateur conspiracy theorists to see gruesome photographs of identifiable deceased persons that are likely to cause their relatives serious emotional harm. No public good would be served by releasing the photographs of the Foster suicide. Finally, it is reasonable to permit family members to protect the privacy of the medical records of their deceased relatives because this right of privacy also protects their own medical privacy.

FAMILY PRIVACY AND SOCIETY

As these examples show, society can pay a price for protecting family privacy. In the case of the Dover test, the daily toll of war dead will be less visible and less directly linked to the American flag, and we may, as Senator McCain suggests, fail to give proper honor and respect to those who die in our country's wars. In the Foster case, someone might be able to 
see in the photographs something no official investigator has seen to date (although this possibility seems extremely unlikely), and the suppression of the photos may fan the flames of conspiracy theories. In the case in Iceland, we make medical research more difficult - by requiring informed consent for the use of medical records of a deceased person if private information about members of that person's family can be disclosed by their use.

In this regard, it is worth noting that the intention of the deCODE project in Iceland was primarily to search DNA samples for genes related to inherited diseases. ${ }^{15}$ DNA is, of course, even more fundamentally a family matter than are medical records that contain family histories. DNA provides direct information not only about the person from whom the sample is taken but also about siblings, parents, and children. This familial nature of DNA has led some to suggest that DNA could be treated as joint information about the entire family, rather than as private information about individual family members. ${ }^{16}$

This tension will pervade many physicians' offices as DNA-based tests are introduced: Under what circumstances should the DNA information obtained from a patient that indicates that a relative is at a much higher risk for a specific, preventable disease be disclosed to that relative? Currently, the best legal and ethical advice is to maintain the patient's privacy and to counsel the patient to make the information about genetic risk known to the family member at risk, and for the physician not to disclose it directly to that family member. ${ }^{17}$ Of course, after the patient dies these examples would all support the physician in disclosing information based on DNA about the deceased person to family members for whom it might have important health implications.

We have come a long way from ancient Greece, but the lessons of Antigone (and Hippocrates) continue to be instructive. How far we will ultimately go in protecting family privacy in the context of death will depend on how highly we value family privacy when weighed against competing values of our society. Put another way, how important do we think family privacy is as a family value?

From the Department of Health Law, Bioethics, and Human Rights, Boston University School of Public Health, Boston.

1. Stanley A. Anne Sexton: controversy surrounding the biography — poet told all; therapist provides the record. New York Times. July 15, 1991:A1.

2. Religion and Ethics NewsWeekly. PBS. June 25, 2004 (transcript).

3. JB Pictures v. Dept. of Defense, 86 F.3d 236 (D.C. App. 1996).

4. Letter of USAF Col. Laurel A. Warish to Russ Kick, dated April 14, 2004. (Accessed January 14, 2005, at http://www. thememoryhole.org/war/coffin_photos/dover.)

5. Davies F. Military families reveal mixed feelings on casket photos. Miami Herald. April 24, 2004:A1.

6. Kornblut AE, Bender B. Pentagon to review photo ban. Boston Globe. April 24, 2004:Al.

7. Stolberg SG. Senate backs ban on photos of G.I. coffins. New York Times. June 22, 2004:A17.

8. Clinton B. My life. New York: Alfred A. Knopf, 2004:531-2.

9. Favish v. Office of Independent Counsel, 37 Fed. Appx. 863 (9th Cir. 2002).

10. National Archives and Records Administration v. Favish, 541 U.S. 157 (2004).

11. Annas GJ. Rules for research on human genetic variation - lessons from Iceland. N Engl J Med 2000;342:1830-3.

12. Gulcher JR, Stefansson K. The Icelandic Healthcare Database and informed consent. N Engl J Med 2000;342:1827-30.

13. Guomundsdottir v. Iceland, Icelandic Supreme Court, No. 151/ 2003. (Accessed January 14, 2005, at http://www.mannvernd.is/ english.)

14. Abbott A. Icelandic database shelved as court judges privacy in peril. Nature 2004;429:118.

15. Merz JF, McGee GE, Sankar P. "Iceland Inc."? On the ethics of commercial population genomics. Soc Sci Med 2004;58:1201-9.

16. Parker M, Lucassen AM. Genetic information: a joint account? BMJ 2004;329:165-7.

17. Offit K, Groeger E, Turner S, Wadsworth EA, Weiser MA. The "duty to warn" a patient's family members about hereditary disease risks. JAMA 2004;292:1469-73.

Coppright $\odot 2005$ Massachusetts Medical Society. 